ACTA AGROBOTANICA

Vol. 59 z. 22006

s. 2942

\title{
Anatomy and ultrastructure of floral nectaries of Asphodelus aestivus Brot. (Asphodelaceae)
}

\section{ELŻBIETA WERYSZKO-CHMIELEWSKA ${ }^{1}$, THOMAS SAWIDIS ${ }^{2}$, KRYSTYNA PIOTROWSKA ${ }^{1}$}

\author{
'Department of Botany, Agricultural University, Akademicka 15, 20950 Lublin, Poland \\ ${ }^{2}$ Department of Botany, University of Thessaloniki, GR 54006 Thessaloniki, Greece
}

(Received: 15.09.2006)

\section{Summary}

The structure of septal nectaries in Asphodelus aestivus flowers was investigated by using light microscopy (LM), scanning electron microscopy (SEM) and transmission electron microscopy (EM). It was found that the outlets of the three parts of the nectary were situated on the ovary surface at $2 / 3$ of its height and had the shape of elongated openings. The nectariferous tissue was in the septa of the lower part of the ovary. The secretory tissue cells formed 1-3 layers surrounding the nectary slits. They contained thin cell walls with the cuticle layer from the slit side, large cell nuclei, numerous mitochondria and plastids characterised by various shapes. In plastids, small starch grains occurred sporadically. At the beginning of anthesis, the cells were poorly vacuolized. ER cisternae and secretory vesicles were located near the outer cell wall. Fibrous substance was present in the nectary slits. In the subglandular tissue, numerous starch grains occurred at the beginning of anthesis. In this zone, cells containing raphides and xylem elements were observed. Based on the ultrastructure of the nectary it can be stated that granulocrine nectar secretion occurs in A. aestivus.

Key words: flower, septal nectaries, anatomy, ultrastructure, Asphodelus aestivus

\section{INTRODUCTION}

As concerns the pollen and nectar produced, species of the genus Asphodelus are included among valuable melliferous plants (Floris et al. 1996; L if a n te, 1996; Prot a et al. 1997).

Asphodelus aestivus Brot. occurs in natural sites in South Europe countries where it can form single-species meadows. It is found in olive groves, open pine 
forests, on rocky slopes, seashores, waste ground and roadsides. Root tubers of this plant are used as food for humans and animals ( $\mathrm{S}$ a w i d i s et al. 2005).

Nectar, abundantly secreted by A. aestivus flowers, is produced in nectaries located inside the ovary. In monocotyledons, S mets et al. (2000) described two main types of nectaries: gynopleural (septal) and perigonal (androecial et tepalar). Within the order Asparagales, to which Asphodelaceae belong, the former type of nectaries occurs. Septal nectaries in Asphodelus are situated in the septa of the trilocular ovary. They have the form of slits lined with glandular tissue forming the epithelium layer. Nectar produced in them gets outside through an outlet of a tubular nature, located on the surface of the ovary (E s a u , 1973).

In terms of the method of nectar secretion, using the histological division presented by Voge 1 (1977) and S c h mid t (1988), these nectaries can be included in epidermal nectaries.

The aim of the study was to investigate the structure of septal nectaries of Asphodelus aestivus by using various microscopy techniques and to determine places of nectar release in flowers of this taxon.

\section{MATERIAL AND METHODS}

Flowers of Asphodelus aestivus were collected about $25 \mathrm{~km}$ southwest of Larissa, Thessaly, Central Greece.

Material for examination in scanning electron microscope (SEM) was fixed in $4 \%$ glutaraldehyde in $0.1 \mathrm{M}$ phosphate buffer ( $\mathrm{pH} 7.0$ ) for 4 hours at room temperature. Samples were dehydrated in ethanol series and acetone and dried at critical point with liquid $\mathrm{CO}_{2}$ and coated with gold and platinum by using the Polaron SC 7640 sputter coater. Observations were made in the microscope BS340 Tesla.

Semi-thin preparations from transverse and longitudinal ovary sections were used for the anatomical analysis of the nectaries. The material was fixed and immersed in synthetic resin in accordance with the method applied to the transmission electron microscope. Semi-thin sections $(0.50 .7 \mathrm{~mm})$ were stained with $1 \%$ methylene blue with $1 \%$ azur II in a $1 \%$ aqueous solution of sodium tetraborate.

Ultrastructural examination of nectary tissues was conducted after the fixation in $2.5 \%$ glutaraldehyde and $2 \%$ paraformaldehyde in $0.05 \mathrm{M}$ cacodylate buffer for 3 hours. After post-fixation in $2 \%$ osmium tetroxide and dehydration in an ethanol series, the samples were embedded in Spurr's epoxy resin. Ultrathin sections $(0.08 \mu \mathrm{m})$ were cut in a Reichert Jung Ultracut $\mathrm{E}$ ultramicrotome and examined using a Zeiss $9 \mathrm{~S}-2$ transmission electron microscope (TEM).

PAS reaction was used for polysaccharide staining. Semithin sections were treated with the periodic acid-Schiff's reagent according to $\mathrm{Ne} v$ a l a i n e n et al. (1972). 


\section{RESULTS}

\section{Scanning electron microscope (SEM) observations.}

The spherical, superior ovary of Asphodelus aestivus has six distinct furrows. Nectar secretion takes place through three outlets located at the $2 / 3$ height of the ovary in the hollows between adjacent carpels (Figs. 1,2). The inferior ovary is green and it is enclosed by a cap which is formed by six flaps, each coming from the base of every stamen.

The opening of the nectary has the form of a groove which may be of different lengths (Figs. 3, 4). In younger flowers, the opening is small before the start of secretion (Fig. 3), whereas during anthesis it grows much longer (Figs. 4,6). We have observed the remnant of the nectar on the adjacent of the outlets surface of the ovary (Figs. 4, 5). In the ovary epidermis, we did not notice any stomata. On the outer epidermis cell wall, there occurred circular wax structures (Fig. 6). The epidermal cells of the ovary surface have been observed to be nearby polygonal in outline and strong realief.

\section{Light microscope (LM) observations.}

The tripartite septal nectary was situated in the lower and middle part of the hemisyncarpous ovary. At the beginning of anthesis, the nectariferous tissue was well differentiated. At this time, on the cross section of the ovary gynopleural nectaries of Asphodelus aestivus, there were narrow cavities (slits) in the middle part of the septal region between two adjacent carpels (Fig. 7). The cavities were lined with secretory tissue which created 1-3 layers of the epithelium. In the outer part of the ovary, septum nectary slits were surrounded by more cell layers (2-3) than in the inner part, where we noticed only one layer of epithelium cells (Figs. 8-9).

On the longitudinal section, the nectary tissue looked similar. Glandular epithelium cells enclosed narrow septal slits of irregular shape. In the slits, we observed dark substance secreted (Fig. 10). Nectar secretion leads to an expansion of the space between the septa.

We recorded mostly one or two layers of epithelium which consisted of palisade or polygone cells. Each layer of epithelium was made up of the cells closely adpressed to the next ones (Figs. 8, 9).

The epithelium cells looked more deeply stained than the surrounding subglandular parenchyma cells (Figs. 7, 8). The cytoplasm of epithelium cells was dense and each of them had a large, centrally situated nucleus. The protoplasm was characterised by poorly developed vacuome in reverse to the subglandular parenchyma cells. Some of the epithelium cells had undergone a division.

The use of reagents which produce the PAS reaction allowed the exact location of starch in tissues examined (Figs. 11-13). Microscopy observations carried out at the beginning of anthesis show that starch grains occur mainly in subglandular tissue cells. In cells forming the epithelium of the nectary, starch grains occurred sporadically and they were much smaller than in subglandular parenchyma cells. 

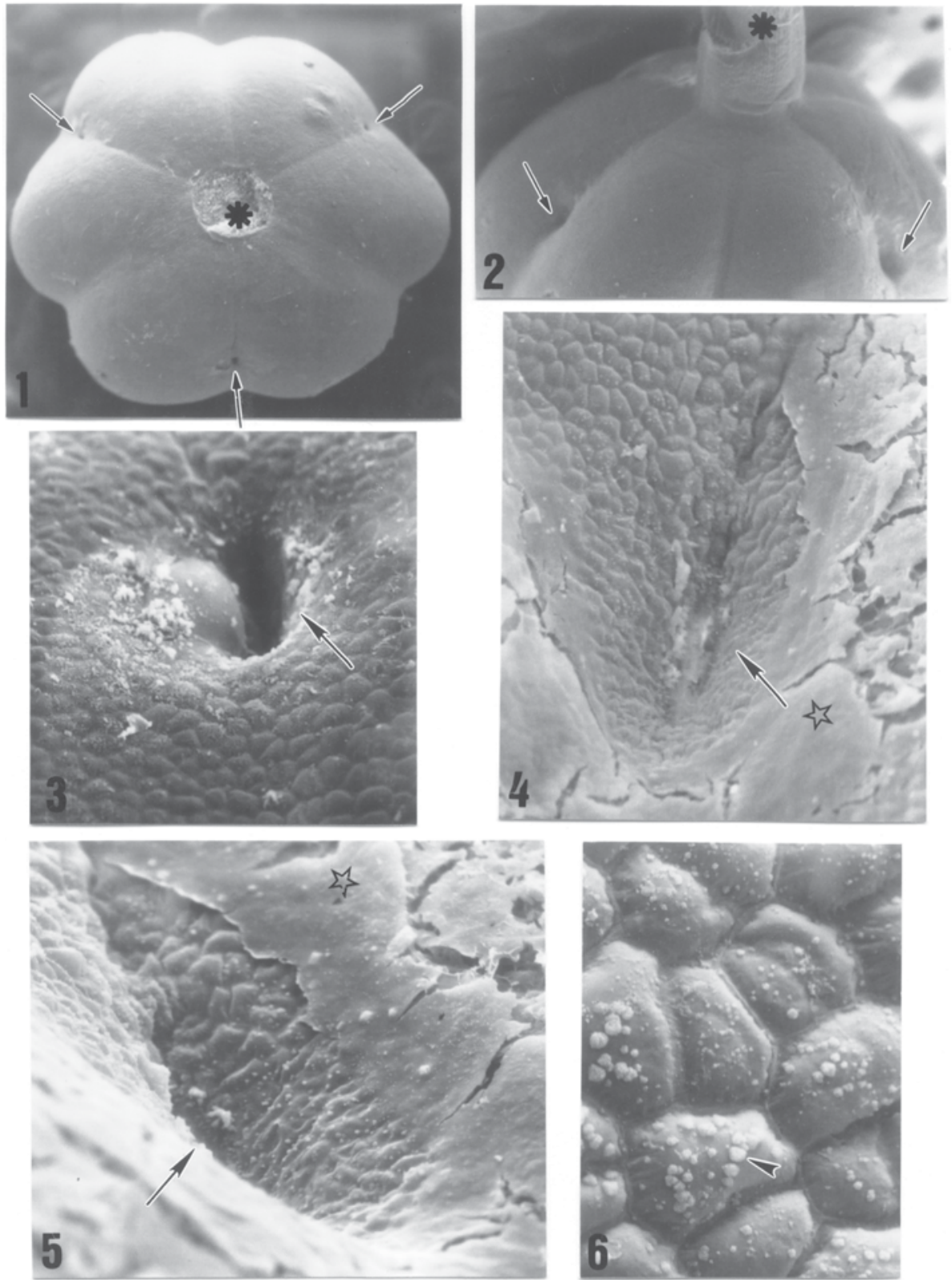

Figs. 1,2. Septal nectaries outlets (arrows) on the ovary surface and style (asterisk) of Asphodelus aestivus, SEM, 1 x 20, 2 × 30.

Figs 3 6. Surface of ovary epidermis with remnants of nectar (asterisk) in the vicinity of nectari ferous outlets (arrows), SEM. 3 x 300, 4 x 300, 5 x 400, 6 × 1250. 


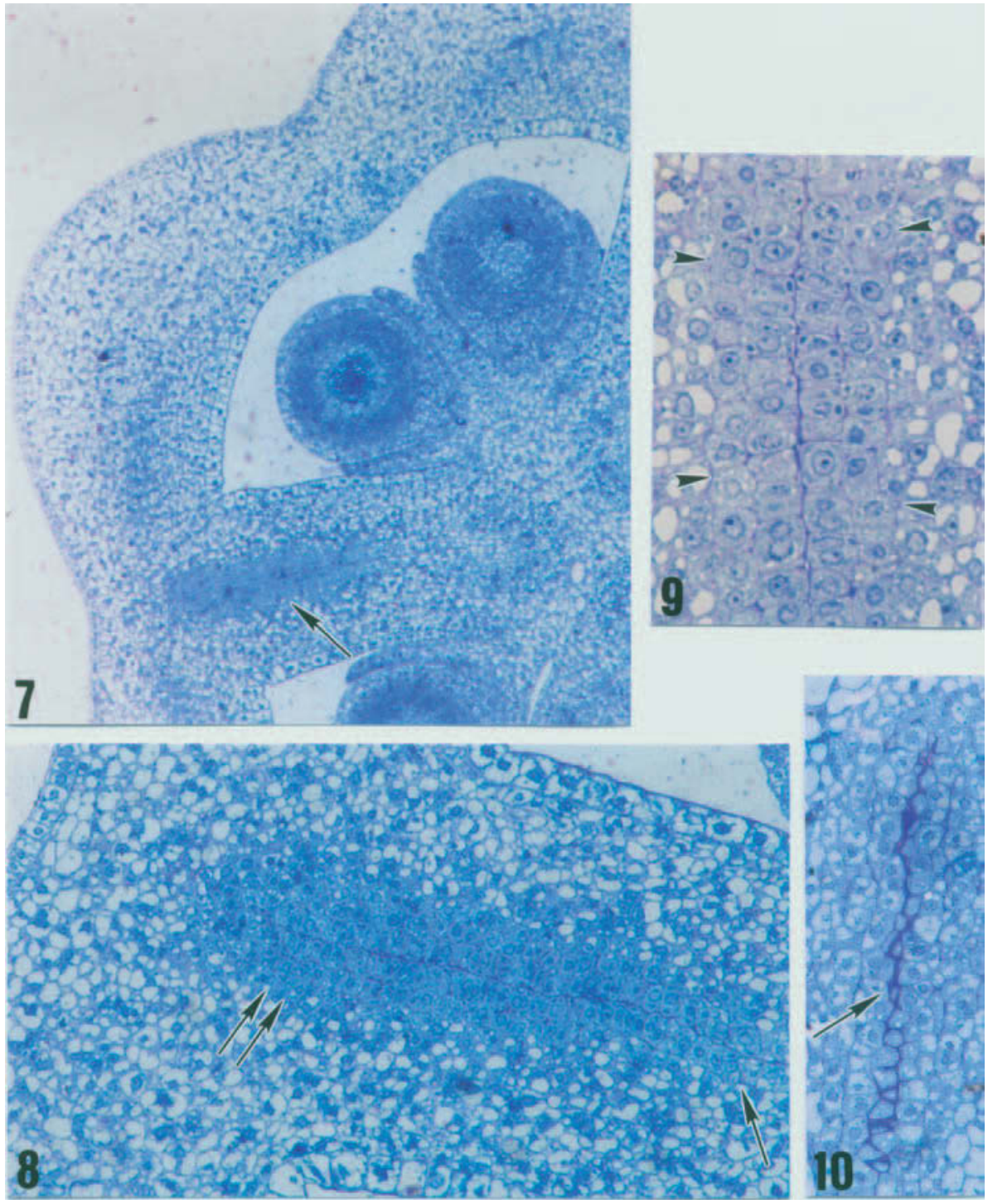

Fig. 7. Fragment of the cross section of ovary with visible septal nectary (arrow), (semithin sections), x 70 .

Figs. 8 10. Septal nectaries sections with several layered glandular tissue (arrows).

8,9 cross sections, $8 \times 170,9 \times 360,10$ longitudinal section, $x 170$. 

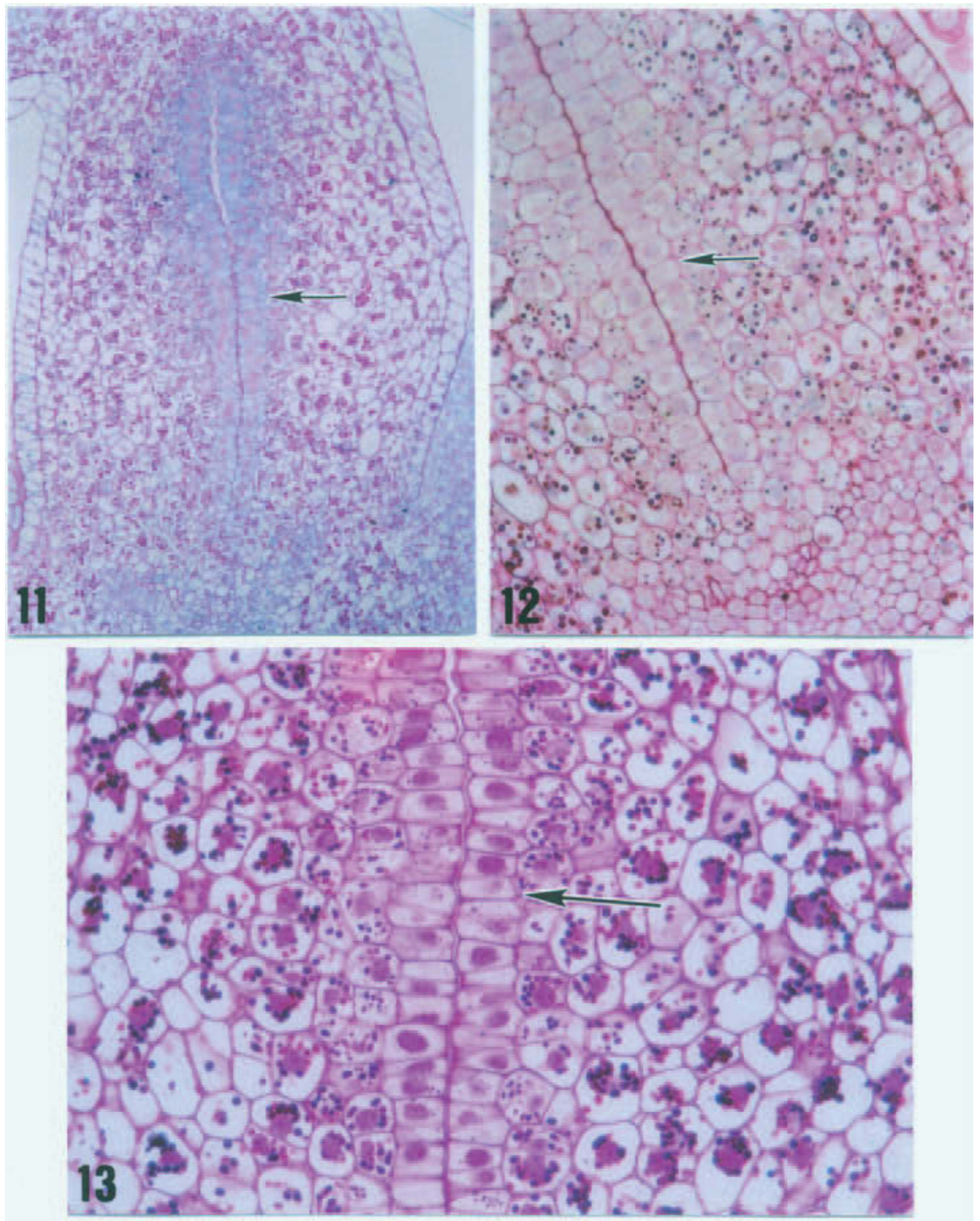

Figs. 11 13. Ovary septa on the cross sections with nectariferous tissue (arrows) (PAS reaction). In the cells visible stained starch grains. 11 x 90, 12 x 130, 13 x 300 . 

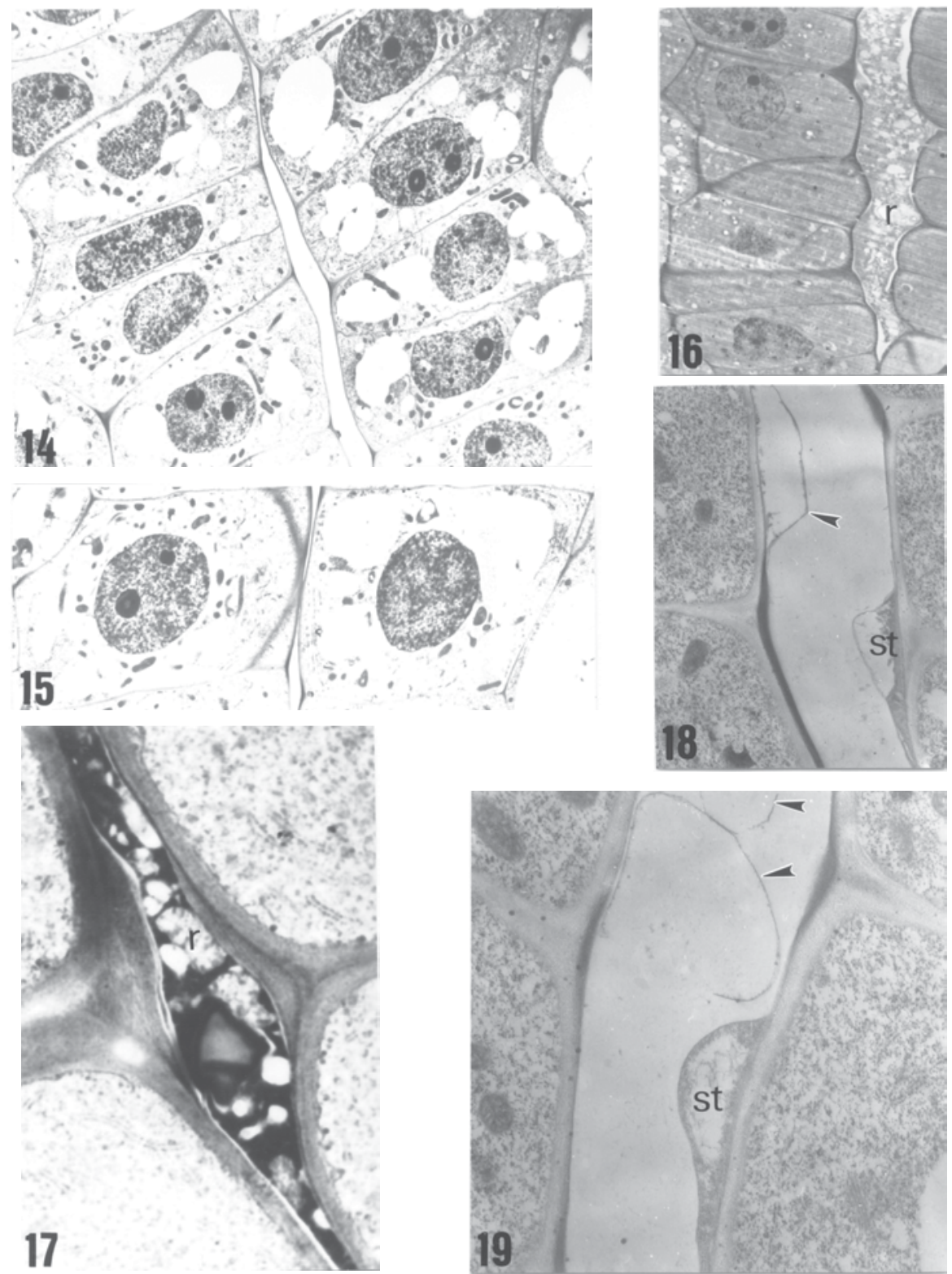

Figs. 14, 15. Fragments of the epithelial layers in different age (EM). 14 The cells at the beginning of anthesis, $\mathrm{x} 1820$,

15 The cells at full anthesis, $x 1820$.

Figs. 16 19. Fragments of the epithelial layers and slits with different content (EM). 16, 17 Visible cytoplasmic remnants (r) in the slits, 16 x. 2000, 17 x 27000 , 18,19 Septal slits with secretion (st) and separated fragments of cuticle (arrowheads), 18 x $20000,19 \times 23000$. 

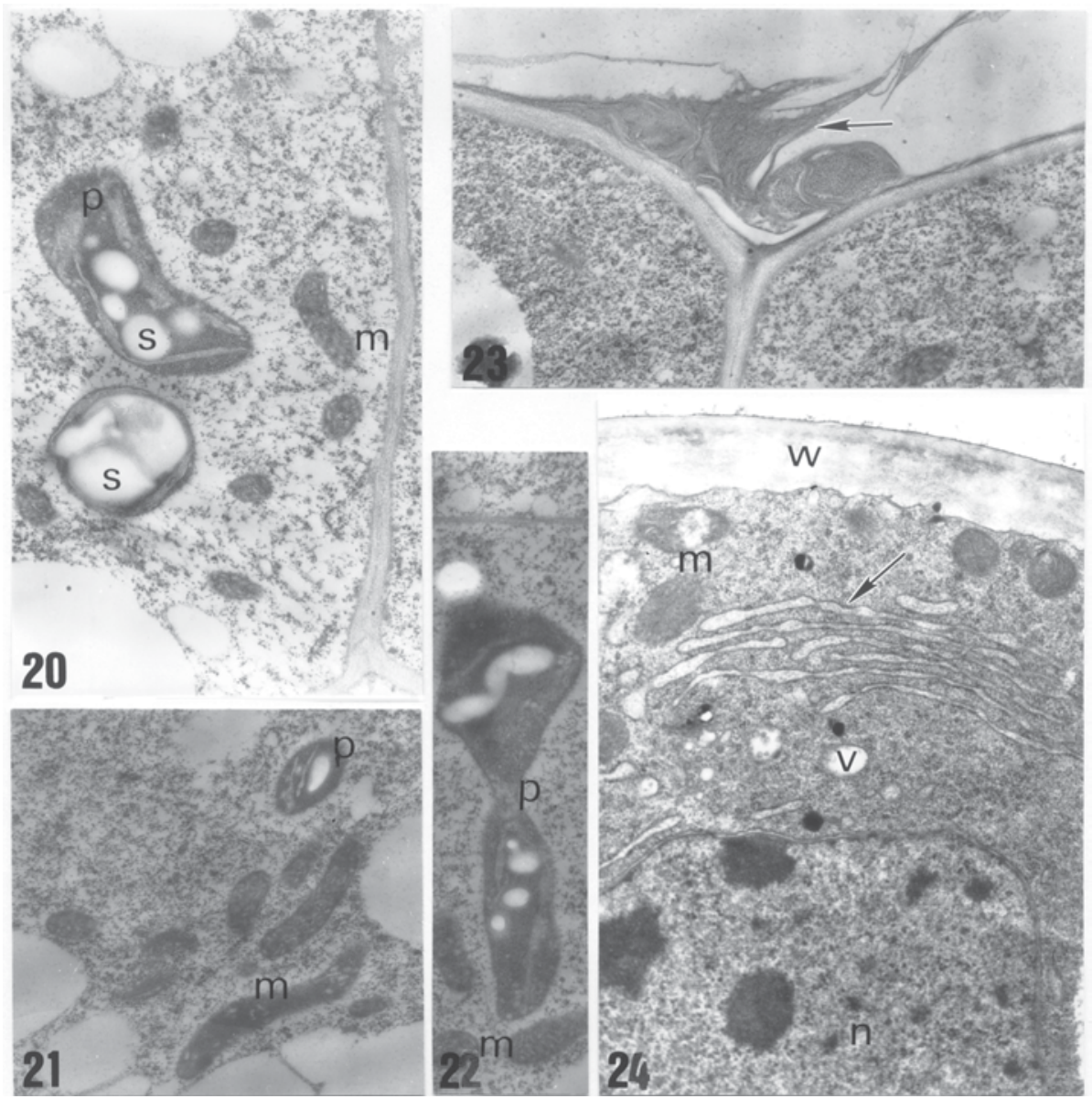

Figs. 20 24. Parts of epithelium cells (EM).

20 Plastids(p) with starch grains (s) and numerous mitochondria (m), x 23000 ,

21, 22 Different shaped mitochondria (m) and plastid (p),

$21 \times 13000,22$ x 23000 ,

23 Flockular substance, possible nectar, in the septal slit (arrow), x 20000.

24 Fragment of nucleus (n), numerous mitochondria (m), vesicles (v), and ER cisternae (arrow) at the outer cell wall (w) of the epithelial cell, x 20000. 

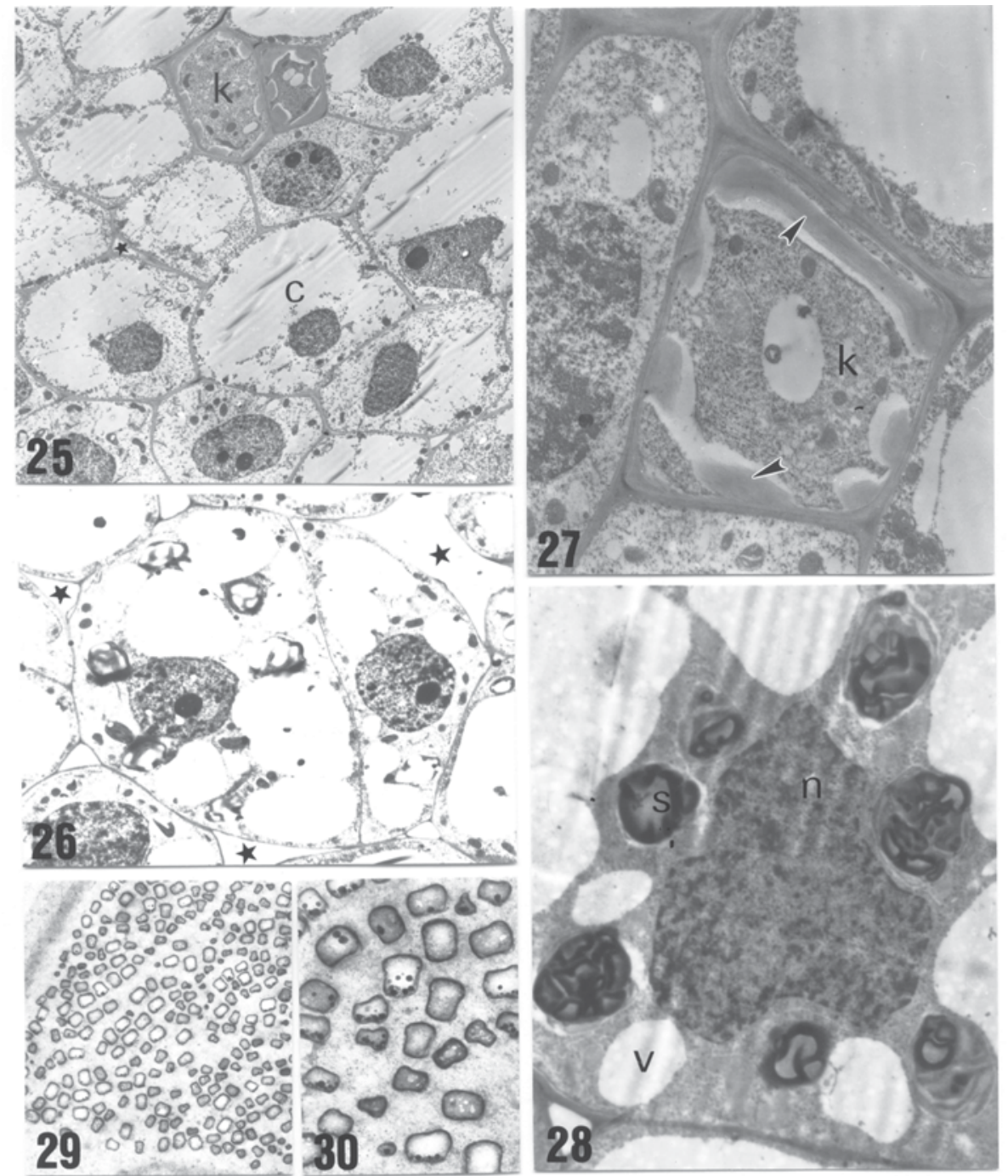

Figs. 25 30. Details of the subglandular tissue (EM).

25, 26 Strong vacuolized parenchymatic cells (c) and xylem elements (k).

In parenchyma visible large intercellular spaces (asterisks),

$25 \times 900,26 \times 3000$.

27 Xylem element $(\mathrm{k})$ with reinforcements of the cell wall (arrowheads), $\mathrm{x} 3000$.

28 A part of the cell with the nucleus (n) of the irregular shape,

numerous plastids with the starch grain (s) and vacuoles (v), x 8000.

29, 30 Cross section of raphide crystals of wide morphological variations.

Electron dense substances penetrate raphide surface, 29 x 1300,

$30 \times 4000$. 

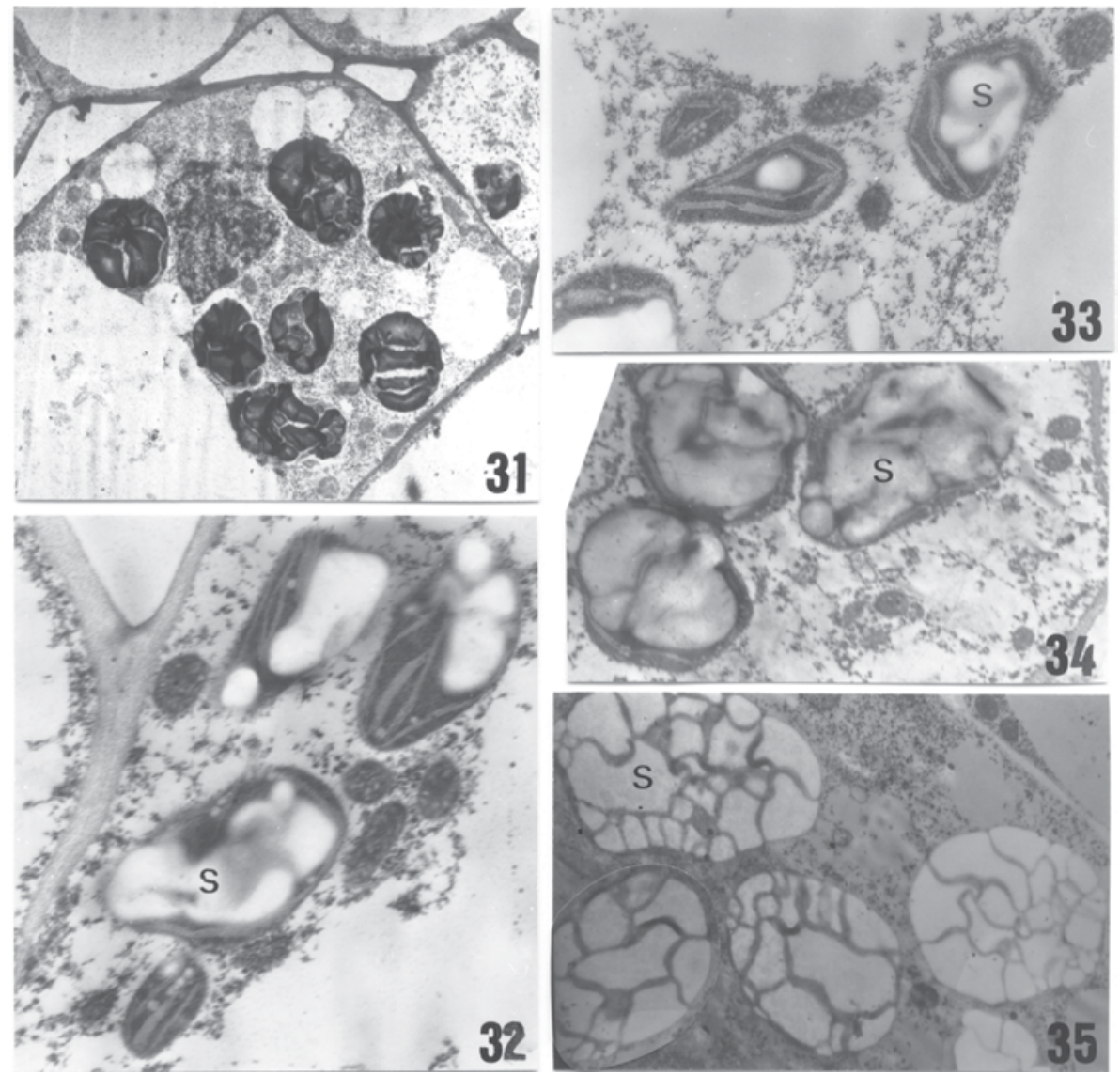

Figs. 31 35. Fragments of cells of the subglandular layer with many plastids with complex starch grains (s). 31 x 2000, 32 x 20000, 33 x 17000, 34 x 20000, 35 x 23000.

\section{Electron microscopy (TEM) observations.}

At the beginning of anthesis, septal epidermis (epithelium) cells were elongated and quite poorly vacuolized. Their walls were very thin (Fig. 14). At the end of flowering, these cells had larger vacuoles and much larger dimensions (Fig. 15). In the epithelium layer, stomata were absent.

In the nectariferous slits, at the beginning of anthesis we observed structures like cytoplasmic remnants (Figs. 16, 17), what may evidence lysigenous ontogeny of septal slits. During nectar secretion, in the nectariferous cavities an amorphous substance occurred, which could be secretion. In some places, this substance was surrounded by a thin layer of the cuticle. Separated layers of the cuticle were visible inside the slit of the nectary (Figs. 18, 19). 
In the dense glandular cytoplasm of the epithelial cells, numerous mitochondria, Golgi structures, active ER, ribosomes and some plastids occurred (Figs. 20-24). Variously shaped plastids contained osmiophilic stroma, peripherally located thylakoids and different sized starch grains (Figs. 20-22). Well-developed ER cisternae formed characteristic profiles located in the vicinity of outer walls. They were accompanied by numerous secretory vesicles. A flockular substance, possibly nectar, was observed in the septal slits (Fig. 23).

Subglandular layers were composed of isodiametric cells (Figs. 25, 26). They had large vacuoles and nuclei, as well as many plastids with starch grains (Fig. 28). In some parts of this tissue, intercellular spaces were very large (Fig. 26).

Complex starch grains occurring in cells of the subglandular layer were made up of partial grains which were of various shapes and different sizes (Figs. 31-35).

The nectary was supplied directly with well developed vascular tissue. The secretory tissue was innervated exclusively by phloem strands. Xylem components were noted in subglandular parenchyma (Figs. 25, 27).

In some cells of subglandular layers, calcium oxalate crystals were observed (Figs. 29, 30). These raphide idioblasts contained bundles of needle-shaped calcium oxalate crystal. Isolated thin-walled crystalliferous idioblast also crystals occured in the ovary, in the fleshy parts of the sepals. These crystals are stored rather passively in larger vacuoles of unmodified cells with a well distinctive tonoplast. Raphide bundles appear in packs and wide morphological variations among the cross sections. Some electron dense substances penetrate the raphide surface and raphide grooves. Tannins are evenly distributed through the floral parts. The granular remnants observed in vacuoles mainly after tissue treatment in fixative vapors are of the same nature.

\section{DISCUSSION}

In this paper, we show that tripartite nectaries of Asphodelus aestivus are located in septal slits of the lower and middle part of the ovary and their outlets have the form of elongate grooves which are situated above the middle part of the ovary. These results differ from $\mathrm{S}$ m e t s et al. (2000) data which describe that nectar in Asphodelus flowers is secreted at the top of the ovary.

The site of the septal nectaries is diverse in the ovary in different representatives of monocotyledons. In some taxa, nectaries are situated at the base of the ovary with the outlet in the same region Johnsonia, Lomandra, Tofieldia (S m e t s et al. 2000). In other genera, the nectary occupies the septal slits only in the upper part of the ovary with the outlet near the style base Haemanthus, Astelia, Yucca (S m e t s et al. 2000), Haworthia and Gladiolus (We berling, 1992) and Acidanthera (We ry s zko-Chmi e lew s ka et al. 2003).

For Allium (Alliaceae), M a u rizio and Grafl (1969) described the distribution of the opening of the septal nectary at the half of the ovary height. This location is similar to the position of the outlets of the Asphodelus nectary.

In Asphodelus nectaries, the epidermis of the septal slits participates in nectar secretion. We did not notice any stomata in the nectary epidermis or on the ovary 
surface. It agrees with the statement of Endress (1995) that nectarostomata are usually absent from monocotyledons.

Septal slits in the Asphodelus nectary were surrounded by 1-3 layers of epithelial cells. In other plants, mostly only one layer of the nectariferous tissue occurred in the septal nectaries (Fi ordi and Pal andri, 1982; We berling, 1992; S met s et al. 2000).

Gynopleural septal nectaries are considered the most advanced in the philogenetical development of plants. Many studies show that the migration of nectary glands proceeds in flowers from the perianth to internally located organs (F a h n, 1953; E s a u, 1973).

In subglandular tissue cells, the presence of raphides was found. In monocotyledons, raphides are the most common type of calcium oxalate crystals. In Asphodelaceae, they are often present at the same time as styloids (Prychid and R u dall, 2000).

Many plant cells contain crystalline inclusions of different chemical composition and shape. Calcium oxalate needles in ovary cells are typical for raphide bundles found in other parts of $A$. aestivus. In root tubers a greater variation of morphological differences of raphide cross sections was observed ( $\mathrm{S}$ a w i d is et al. 2005), probably due to various crystallization degrees, stage of development and penetration depth of electron dense substances. In root tubers the need to fight herbivores seems to be more vital. Such morphological differences of raphides could potentially influence the degree of acridity. Raphides could also play a role in penetration and carrying acrid factors on their surfaces and in their grooves, for instance, lipid substances impregnated with oxalic acid. The high level of acridity in A. aestivus root tubers has been associated partly with the sharpness and size of its raphides (E s a u, 1973).

Raphides store calcium oxalates as metabolic waste or by-product of plant tissues. Accumulation of oxalic acid in tissues, which is not readily metabolized, may cause osmotic problems. Therefore, precipitation of calcium oxalate crystals seems to be an appropriate way for the plant to avoid these undesirable situations. The relationship between calcium ion absorption and oxalic acid synthesis in plants is most probably established for ionic balance in tissues to be maintained (B o s a b a li d is 1987). On the other hand, the calcium content in both root tubers and nectaries may be viewed as an osmoregulatory mechanism during the secretion process ( $\mathrm{E} 1 \mathrm{Ch}$ o n e my et al. 1978; Levit t, 1980; Evan s et al. 1992).

The protection of $A$. aestivus raphides against herbivore attacks is reinforced by other cells containing defense compounds, such as alkaloids, found in other parenchymatic tissues supporting the nectary ( $\mathrm{Ham}$ mouda et al. 1971; S a w i d is et al. 2000; Wittstock and Gershenzon 2002).

Based on features of the ultrastructure of glandular cells it can be determined which pathway of nectar transport from inside to the outside of the nectariferous cells occurs. In A. aestivus, the occurrence of numerous mitochondria, the abundance of active ER and numerous Golgi structures were found. Ameboidal plastids contained few starch grains. The abovementioned features of protoplasts of nectariferous cells 
indicate granulocrine secretion in this species (R a chi mile vitz and Fah n, 1973; Fahn and Ben ouaiche, 1979).

The investigations show that nectar secretion from cells of the epithelial layer to the A. aestivus nectary slit takes place through a relatively thin cellulose wall. Nectar collects outside between the wall and the bulging layer of the cuticle, which then bursts, causing the release of nectar. After the nectary slit is filled up to about half of the height of the ovary, where the outlet of the nectary is situated, nectar flows outside and stops on expanded parts of filaments and perianth tepals.

\section{REFERENCES}

B os abalid is A. M., 1987. Origin, ultrastructural estimation of possible manners of growth and non morphometric evaluation of calcium oxalate crystals in nonidioblastic parenchy ma cells of Tamarix aphylla L. J. Submicrosc. Cytol., 19 (3), 423432.

E1 Chonemy A. A., Wallace A., Romney E. M., Dowaidar S., E1 Gazzar A., 1978. Potentialities of plant with underground storage organs in Egyptian Desert Flora. I. The inorganic composition of the plant tissue. Economical Botany 32: 7586.

Endress P. K., 1995. Major evolutionary traits of monocot flowers. [In:] Monocotyledons: Systematics and Evolution. P. J. Rudall, P. J. Cribb, D. F. Cutler and C. J. Humphries (eds.), pp. 43 79. Royal Botanic Garden: Kew, London.

Es a u K., 1973. Anatomia roślin. PWRiL, Warszawa.

Evans R. D., Black R. A., Loescher W. H., Fellows R. H., 1992. Osmotic relations of the drought tolerant shrub Artemisia tridentata in response to water stress. Plant Cell Environ. 15: 4959.

Fahn A., 1953. The topography of the nectary in the flower and its phylogenetic trends. Phyto morphology, 3: 424426.

Fahn A., B en ouaiche P., 1979. Ultrastructure, development and secretion in the nectary of banana flowers. Ann. Bot. 44: 8593.

Fiordi A. C., Palandri M. R., 1982. Anatomic and ultrastructural study of the septal nectary in some Tillandsia (Bromeliaceae) species. Caryologia, 35 (4): 477489.

Flor is I., Prota R., Fad da L., 1996. Quantitative pollen analysis of typical Sardinian honeys. Apic. Mod. 87 (4): 161167.

Hammouda F. M., Rizk A. M. and Abdel Gawad M. M., 1971. The alkaloids of Aspho delus microcarpus. Current Sci. (India) 40: 631632.

Levitt J., 1980. Responses of Plants to environmental stresses. Vol. II. Physiological Ecology Series. Academic Press Inc., New York.

Lif ante D. Z., 1996. Reproductive biology of Asphodelus albus (Asphodelaceae). Plant Syst. Evol. 200: 177191.

Maurizio A., Grafl I., 1969. Das Trachtpflanzenbuch. Ehrenwirth Verlag, München.

Nevalainen J. J., Laitio M., Lindgren I., 1972. Periodic acid schiff (PAS) staining of Epon embedded tissues for light microscopy. Acta Histochem. 42: 230233.

Prota R., Floris I., Pa poff C. M., 1997. Comparison of the chemical and physical characte ristics of Sardinian and Corsican honeys. Apic. Mod. 88 (2): 5159.

Prychid Ch. J., Rudall P. J., 2000. Distribution of calcium oxalate crystals in monocotyle dons. [In:] Monocots: Systematics and Evolution, K. L. Wilson, D. A. Morrison (eds.), CSIRO, Melbourne. 
Rachimilevitz T., Fahn A., 1973. Ultrastructure of nectaries of Vinca rosea L., Vinca major L. and Citrus sinensis Osbeck cv. Valencia and its relation to the mechanism of nectar secretion. Ann. Bot. 37: 19.

Sawidis T., Dafnis S., Weryszko Chmielewska E., 2000. Distribution and structure of resin ducts in Pistacia lentiscus var. chia Duhamel. Flora 195: 8394.

Sawidis T., Kalyba S., Delivopoulos S., 2005. The root tuber anatomy of Aspodelus aestivus. Flora 200: 332338.

Schmid R., 1988. Reproductive versus extra reproductive nectaries historical perspective and terminological recommendations. Bot. Rev. 54: 179232.

Smets E. F., Ronse Decraene L. P., Caris P., Rudall P. J., 2000. Floral nectaries in monocotyledons: distribution and evolution. [In:] Monocots: Systematics and Evolution, K. L. Wilson, D. A. Morrison (eds.), CSIRO, Melbourne.

Vogel S., 1977. Nektarien und ihre ökologische Bedeutung. Apidologie, 8: 321335.

Weberling F., 1992. Morphology of flowers and inflorescences. Cambridge Univ. Press, Cam bridge.

Weryszko Chmielewska E., Masierowska M., Laskowska H., 2003. Budowa nektarnika acidantery dwubarwnej murielskiej (Acidanthera bicolor var. murielae Perry). Ann. Univ. Mariae Curie Skłodowska, Sect. EEE Hortic. XIII: 123127.

Wittstock U., Gershenzon J., 2002. Constitutive plant toxins and their role in defence against herbivores and pathogenes. Curr. Opin. Plant Biol. 5: 18.

\section{Anatomia i ultrastruktura nektarników kwiatowych Asphodelus aestivus Brot. (Asphodelaceae)}

\section{Streszczenie}

Strukturę nektarników przegrodowych w kwiatach Asphodelus aestivus badano przy pomocy mikroskopii świetlnej (LM), skaningowej elektronowej (SEM) oraz transmisyjnej elektronowej (TEM).

Stwierdzono, że ujścia trzech części nektarnika położone są na powierzchni zalążni na 2/3 jej wysokości i mają kształt podłużnych otworów. Tkanka nektaronośna znajdowała się w przegrodach dolnej części zalążni. Komórki tkanki sekrecyjnej tworzyły 1-3 warstwy otaczające szczeliny nektarnika. Zawierały cienkie ściany komórkowe z warstwą kutykuli od strony szczeliny, duże jądra komórkowe, liczne mitochondria i plastydy charakteryzujące się różnorodnym kształtem. W plastydach sporadycznie występowały niewielkie ziarna skrobi. Na początku kwitnienia komórki były słabo zwakuolizowane. Cysterny ER i pęcherzyki wydzielnicze położone były w pobliżu zewnętrznej ściany komórkowej. Włóknista substancja była obecna w szczelinach nektarnika. W tkance podgruczołowej na początku antezy występowały liczne ziarna skrobi. W strefie tej obserwowano komórki zawierające rafidy oraz elementy przewodzące ksylemu. Na podstawie ultrastruktury nektarnika można stwierdzić, że u A. aestivus występuje granulokrynowa sekrecja nektaru. 